\title{
Analyzing Postgraduates' Motivation in Writing Master Dissertation
}

\author{
Azizan Zainuddin, Memiyanty Abd Rahim, Radduan Yusof, Suhaimi Abd \\ Samad, Nor Hafizah Mohamed Harith, Noor Hanim Rahmat
}

To Link this Article: http://dx.doi.org/10.6007/IJARBSS/v11-i12/11460

DOI:10.6007/IJARBSS/v11-i12/11460

Received: 07 October 2021, Revised: 11 November 2021, Accepted: 27 November 2021

Published Online: 14 December 2021

In-Text Citation: (Zainuddin et al., 2021)

To Cite this Article: Zainuddin, A., Rahim, M. A., Yusof, R., Samad, S. A., Harith, N. H. M., \& Rahmat, N. H. (2021). Analyzing Postgraduates' Motivation in Writing Master Dissertation. International Journal of Academic Research in Business and Social Sciences, 11(12), 1199-1220.

Copyright: (c) 2021 The Author(s)

Published by Human Resource Management Academic Research Society (www.hrmars.com)

This article is published under the Creative Commons Attribution (CC BY 4.0) license. Anyone may reproduce, distribute, translate and create derivative works of this article (for both commercial and non0-commercial purposes), subject to full attribution to the original publication and authors. The full terms of this license may be seen

at: http://creativecommons.org/licences/by/4.0/legalcode

Vol. 11, No. 12, 2021, Pg. 1199 - 1220

Full Terms \& Conditions of access and use can be found at http://hrmars.com/index.php/pages/detail/publication-ethics 


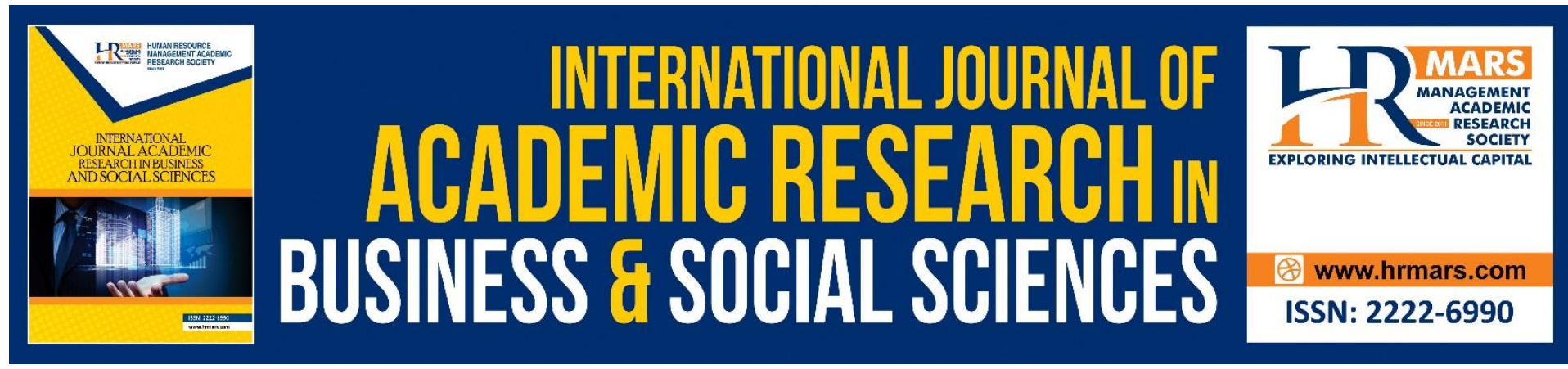

\title{
Analyzing Postgraduates' Motivation in Writing Master Dissertation
}

\author{
Azizan Zainuddin ${ }^{1}$, Memiyanty Abd Rahim², Radduan Yusof ${ }^{3}$, \\ Suhaimi Abd Samad ${ }^{4}$, Nor Hafizah Mohamed Harith ${ }^{5}$, Noor \\ Hanim Rahmat ${ }^{6}$ \\ 1,2,5 Faculty of Administrative Science and Policy Studies, Universiti Teknologi MARA, \\ Selangor, ${ }^{3,4}$ Faculty of Administrative Science and Policy Studies, Universiti Teknologi MARA, \\ Kampus Seremban, ${ }^{6}$ Akademi Pengajian Bahasa, Universiti Teknologi MARA Cawangan \\ Johor, Kampus Pasir Gudang
}

\section{Abstract}

Motivation is an important element in determining students' learning and achievements during their study period. This study investigates problems faced by students in writing a dissertation at the postgraduate level. Postgraduate and research students are found to be under constant pressure which leads to demotivation to finish their studies within the candidacy period. This article utilizes the cross-sectional quantitative research method. The research data were obtained through self-administered online questionnaires that were distributed to 72 postgraduate students from 3 different programs who were selected using the convenient sampling technique. The research participants are those who have opted to write a dissertation as a partial requirement to graduate. The findings were analyzed using mean statistics to explore rhetorical problems learners face in the writing of their dissertation. The findings show that the value component that includes intrinsic and extrinsic goal orientation portrays the respondents' priority to make sure that they can better understand the requirements in writing the dissertation. Nevertheless, results of the study which has been developed under the three main components items namely value, expectancy and affective are useful for teachers to take into consideration the factors that motivate and influence postgraduate students to keep writing their dissertation. Hence, future researchers should consider bringing the study to another level by including students' participation from myriad universities and states to ensure that a better solution can be provided in enhancing students' motivation in writing their dissertation.

Keywords: Motivation, Postgraduates, Writing, Intrinsic, Extrinsic

\section{Introduction}

Background of Study

Dörnyei \& Ushioda (2013) define motivation to describe why people decide to do something, how hard they are going to pursue it and how long they are willing to sustain the activity. Motivation is an inner power reinforcing any person to do something. Meanwhile, writing is a means of communication in which the writer uses the language to express their feeling, 
thought and ideas in written form (Aryanika, 2016). Moreover, writing is the natural outlet for the students' reflection on their speaking, listening, and reading experience. It can be said that writing is the process of sending messages from the writer to the reader. Hence, writing motivation can be defined as the positive power or attitude that comes from inside and outside of the students which can improve the students in their dissertation. It means the students' writing motivation is an inner power inside and outside of the students to do writing activity.

The students will find many problems in writing that can lead their motivation to decrease because it has structure, organization, pronunciation, diction, spelling, and vocabulary. Specifically, in writing, the students are expected to be able to express their ideas systematically into written forms. Students often experience difficulties due to the unusual length of the thesis, the expected level or complexity of its structure and the circumstantial isolation or loneliness of the author (Birkenkrahe, 2014). The increase in length, level and loneliness is significant in comparison with writing a term paper, putting together a project report or composing a presentation. This change can lead to negative emotions, weakens motivation to proceed and causes attitude issues towards the thesis and the entire process connected with it.

\section{Statement of Problem}

Postgraduate and research students are under constant pressure to finish within their candidacy period. The task of discovering new knowledge, performing ground-breaking work, keeping up with the literature, preparing a thesis, publishing, and presenting conference papers comes with that burden (Abiddin \& Ismail, 2011). This problem escalates when students are obliged to write in a language other than their native tongue and utilise a large vocabulary, which will affect their writing confidence (Aryanika, 2016). Because of the difficulty of completing a thesis, several students become unmotivated and drop out or delay their graduation (Rauf, 2016). Delaying graduation can also enhance a student's desire to drop out entirely because of the time and financial implications.

Because of the intrinsic interest, joy, and satisfaction of performing an activity, motivation will manifest itself in participation and engagement (Ryan \& Deci, 2000). Student engagement also refers to a student's desire to participate in the learning process, which motivates them to study and succeed. Students that are highly motivated are more active and interested in completing their task. Student interest and involvement are crucial prerequisites for active learning (Nayir, 2017) and a predictor of success (Harbour et al., 2014). Motivation is crucial not only for inspiring students to learn, but also for assisting them in achieving their goals (Anni, 2006). Students that are motivated to learn and have effective learning habits are more likely to meet the required competency criteria (Tokan \& Imakulata, 2019). Because they place a value on the subject, an interested student will devote themselves to it and perform with excitement and care during the learning process. As a result, highly motivated students will be more engaged in their writing and will acclimate to the learning environment (Aryanika, 2016). On the contrary, the weaker a student's motivation to write, the worse his or her writing abilities. 
Objective of the Study and Research Questions

Hence this study is done to explore rhetorical problems learners face in the writing of their thesis. Specifically, this study is done to answer the following questions;

(1) RQ1-How does audience factor influence learners' motivation to write?

(2) RQ2- How does the exigency factor influence learners' motivation to write?

(3) RQ3-How does the topic influence learners' motivation to write?

\section{Literature Review}

Introduction

Motivation is important in life. It involves drives for positive responses towards certain goals set by individuals and contributes to the decision-making process. Pursuing and to remain sustained in education or studies is one of those. This literature review on factors related to motivation and demotivation for learning and writing among postgraduate's students, along with several related theories are essential to become a guideline in formulating research objectives for this study. The theoretical paradigm proposed in this study was grounded by learners' motivation theory from Pintrich De Groot (1990).

Demotivation and Motivation for learning for postgraduates

The decision to pursue a postgraduate level among students is influenced by many factors. The different nature of teaching and learning process may require the students to give extra effort to meet higher expectations by the program and educator. The main differences are such as deeper and practical analysis on the subjects, the application on the theory and analysis, the fieldwork etc compared to undergraduate level.

Most postgraduate programmes also involve dissertation and thesis writing. To a certain extent, some undergraduate programs have not exposed students with the dissertation based on the nature of the subject. Thus, the internal and external factors such as selfdetermination, career goals as well as universities' reputation, requirement for career ladder have played an important role in determining the motivation and successfulness in studies.

In much research, there are many reasons that can contribute to the students pursuing their studies at the postgraduate level. Research from Greene, Zugelder, Warren and Lesperance (2020) found that the extrinsic reasons that related to time and length of the study has influenced the decision for postgraduate studies. However, it is also supported by programmatic factors such as course expectation, workload, course organization and accessible communication between students and supervisors especially those who are doing research mode. This study was implemented to gauge the responses among teachers who pursued their studies in an online master's degree in education in a state where legislative funding does not provide advanced degree pay. A study in Albania however identified that the motivation to pursue higher level education is derived from three major reasons which are: individual, career oriented and environmental factors (Uka, 2012).

Previous studies have also shown different motivation for different countries and job-related field such as teachers, medical staff, engineers etc. in Thailand for example, Teowkul et.al (2009) has identified the motivational factors for individuals in postgraduate business studies are because of expectation to gain more respect, better compensation, ability to change job easily or smoothly transition in new careers. Meanwhile, a study in Brazil in 2016 by Durso, 
Cunha, Neves \& Teixeira engaged with Self-Determination Theory in understanding motivation among students in the Economic and Accounting field with demographic characteristics as well as insertion in the labour market. The same theory is also applied by Litalien, Guay and Morin (2015) for doctoral studies in Canada and the United States. For science students, there are few reasons that motivate them in postgraduate studies such as, their own interest in the topic they are researched on, the credibility of the supervisors (scientist), the nature of the project with respect to industrial clinical or other applications, the reputation of the university, the intrinsic value that higher degree education can provide better career opportunity and monetary (O'Kennedy, 1990).

In contrast, there are also demotivation factors for higher education as reported by Munyengabe, Haiyan, Liangyan and Yiyi (2017) among Mathematics and Sciences students such as communication barriers, unfit social interaction, advanced software to be used and different high requirement to be accomplished in a research university. Empirically, a study from Ng, Muhd, Ab Rahman and Ismail (2011) has identified six factors that can attract or motivate students for postgraduate studies in Malaysia which are, opportunity, personal attributes, working relevant knowledge, financial Support, program structures and social support.

From a different perspective, other issues and challenges faced by postgraduate students also can be seen from the sustainability in learning process of the attended course or program. Several studies have found that this factor can be influenced by two main reasons which are the individual and the institutional as identified by Heide, Pante, Fleig, Möltner, Leis, Fritz and Fischer (2019). Among the domains are such as little difficulty in choosing the topic, retention of the originally chosen topic, general support by the program administration and timely feedback from the advisor, and the provision of temporal, staff, and financial resources by the home faculty. It is supported by research from Hadi and Muhammad (2019) which also found three important variables in influencing postgraduate students' performance, which are students' personal factor ranked as most influential factor, followed by institutional factor, and supervisor-related factor.

Another research from Chin, Ch'ng, Jamil and Shaharanee (2017) also found quite similar findings from their research in identifying a successful factor for graduate on time among PhD students. The contributing factors are as such; student factor, financial factor, supervisor factor, skills factor, project factors and institution factor.

A study at a university in the Netherlands found that, motivational factors for learning and successful candidate among PhD students are, the quality of the supervisor-PhD candidate relationship, the students' sense of belonging, the amount of freedom in the project, and working on a project closely related to the supervisor's research (Van Rooij, FokkensBruinsma, \& Jansen, 2021). However, Heide, Pante, Fleig, Möltner, Leis, Fritz and Fischer (2019) also recorded the hindrance factor such as the failure to turn in the project report and a lengthy interruption of master thesis work could be identified as a demotivation factor among students. 
Demotivation and Motivation for Writing among postgraduates

Doing research is a complex task that requires different skills, mainly research planning, reading, synthesising information, critical thinking and most significantly effective academic writing skills. For postgraduate students doing research can be challenging. Hence, to be a successful writer, they should gain strong motivation in their ability to perform and complete the complex tasks of writing a research work. Hence, undoubtedly a motivation is the inner driver that determines successful writing activity in postgraduate research work.

Motivation is all of inner power reinforcing any person to do something. By definition, motivation concerns the direction and magnitude of human behaviour, that is the choice of a particular action, the persistence with it and the effort expended on it. In other words, motivation is responsible for why people decide to do something, how long they are willing to sustain the activity, and how hard they are going to pursue it (Dörnyei \& Ushioda, 2011).

Thus, applying the definition into writing motivation, this means it is an inner power that determines successful writing activity. This is particularly significant in the context of writing a dissertation and research project. The students need motivation in writing, because with motivation they will be active in writing activity. On the other hand, 'demotivation' in the following concerns with specific external forces that reduce or diminish the motivational basis of a behavioural intention or an ongoing action (Dörnyei \& Ushioda, 2011). In short, a 'demotivated' learner is someone who was once motivated but has lost his or her commitment or interest for some reason. In other words, demotivation is the negative counterpart of 'motives', in which a motive increases an action tendency whereas a "demotive" decreases it (Komba, 2016). Despite this, demotivation does not mean that all the positive influences that originally made up the motivational basis of a behaviour have been annulled; rather, it is only the resultant force that has been dampened by a strong negative component, and some other positive motives may still remain operational. For example, a learner lost his interest in writing because he has poor writing competencies such as structure grammar, diction, vocabulary and punctuation. To a large extent, a learner needs to stay motivated to progress in his writing journey.

In the context of motivation in writing activity, the motivation of learners can be explained into two types namely intrinsic and extrinsic motivation that drive their writing achievement. According to Ryan \& Deci (2000), intrinsically motivated behaviours, which are performed out of interest and satisfy the innate psychological needs for competence and autonomy are the prototype of self-determined behaviour. Whilst, extrinsically motivated behaviours are those that are executed because they are instrumental to some separable consequence and they can vary in the extent to which they represent self-determination. Internalization and integration are the processes through which extrinsically motivated behaviours become more self-determined. In other words, the intrinsic or internal motivation means the desire to learn coming from students themselves without the need for external inducement and it can result in considerable learning and a minimum of discipline problems. Whereas, extrinsic motivation means the desire to learn coming from rewards and external inducement such as material or monetary rewards. Despite the differences between the two, both intrinsic and extrinsic motivation are significant drivers for successful writing accomplishment. 


\section{Self-Efficacy Beliefs and Writing Motivation}

It is important to explore the students' perceptions of self-efficacy for motivation for writing academic work. Schunk (1991) explains self -efficacy is a person's belief about his or her ability to complete a certain task successfully. Bandura (1997) proposes that self-efficacy is an important drive for intrinsic motivation. He further argues that people develop an "enduring interest in activities at which they feel efficacious and from which they derive selfsatisfaction" (p.219).

According to Bandura (1997), how people behave can often be better predicted by the beliefs they hold about their capabilities, what he called self-efficacy beliefs, than by what they are actually capable of accomplishing, for these self-perceptions help determine what individuals do with the knowledge and skills they have. Self-efficacy boosts learners' competence, confidence and even facilitates learners to set challenging goals. On the other hand, lower confidence limits the learners' sense of accomplishments (Bandura, 1997). Similarly, Pajeras (2010) argues that a strong sense of confidence, for example, may serve students well when writing an essay because it engenders greater interest in and attention to writing, stronger effort, and greater perseverance and resilience in the face of adversity. Confident students are also likely to feel less apprehensive and have stronger feelings of self-worth about their writing.

Self-efficacy has been studied widely in higher education. Previous studies have also shown that self-efficacy beliefs for writing relates positively to academic performance in higher education (Sanders-Reio et al., 2014; Prat-Sala and Redford, 2012). Indeed, many research works have proved the relationship between Bandura's self-efficacy theory and writing accomplishments in academic setting (Floris et al., 2019; Pajares, 2010; Moore, 2003). Writing effectively means the ability of a learner to complete the task successfully. For instance, Moore (2003) found that most students identified a variety of enjoyable dimensions that they associated with the writing process. Most learners felt they achieved a sense of achievement and satisfaction in successful writing. More than $50 \%$ of respondents in her study referred explicitly to an anticipated sense of achievement. She also found that issues of competence and confidence were the most frequently cited dimensions that respondents linked to negative aspects of writing. Participants said that they feared 'not being good enough' and reported that they worried about more specific problems with their writing, such as 'lacking clarity' or 'producing uninteresting, bland material' or 'not really having anything new or fresh to contribute'

Many postgraduate students face many problems in writing their dissertation and theses. This is apparent for non- English speaking background learners. A study conducted by Komba (2016) in three universities in Tanzania found that, from reviews of a total of 103 research reports, including 39 theses and 64 dissertations, the majority of the candidates faced numerous challenges in writing their theses and dissertations. The candidates seemed to have challenges in writing all chapters which were included in their research reports. The challenges included inappropriateness in presenting different chapters of the reports and lack of academic writing skills. Similarly, in a current study on the academic writing needs of postgraduate Research students in Malaysia by Jeyaraj (2020) found that students required support in three main areas: writing, supervision and ICT. First, the students sought English language support and more workshops and programmes which specifically dealt with thesis 
writing. They also believed that peer support groups would be beneficial. Secondly, more guidance was needed from supervisors to enable greater clarity on writing and finally, students wanted greater access to ICT writing tools to facilitate writing and language learning.

Self-regulatory strategies is another attribute of self-efficacy that affecting the intrinsic motivation of the learners. Students' self-efficacy for self-regulation the confidence to use self-regulated learning strategies correlates with writing competence (Zimmerman, Bandura, \& Martinez-Pons, 1992; Zimmerman \& Martinez-Pons, 1990 \& Zimmerman \& Risemberg, 1997). In this case, the students' writing confidence and competence increase when they are provided with process goals (i.e., specific strategies they can use to improve their writing) and regular feedback regarding how well they are using such strategies. Furthermore, it has been observed, however, that even under adverse conditions and without any teacher assistance, some learners are more successful in keeping up their goal commitment than some others (Komba,2016). They are able to do it because they motivate themselves. Therefore, this shows that the students' writing confidence and competence increase when they are provided with process goals (i.e., specific strategies they can use to improve their writing) and regular feedback. Furthermore, being confident is an important self-regulatory strategy that has also been linked to higher intrinsic motivation, adaptive attributions, and academic achievement (Schunk \& Zimmerman, 1994).

This proves that Bandura's (1986) claim that self-efficacy beliefs play an influential role in academic achievement. An important implication to emerge from these findings is that it is significant to improve the self-efficacy of learners to boost their motivations in writing activity and self-regulating or self-motivating in order to achieve successful writing composition.

Past Studies Learning for Postgraduates

A key survey from the survey of Malaysian Domestic Students by QS Enrollment Solutions presented that career focus, wanting to advance to postgraduate studies and personal interests are the main motivations for prospective students from the country to pursue their higher education. Most of the scholars who have conducted studies on postgraduate students have touched on issues of experience as well as challenges faced by postgraduate students. This is because postgraduate students are mostly composed of those who are mature, have a career as well as have great responsibilities towards the family (Im Bok, 2021).

Most of the scholars who study about the postgraduate students usually touch on the student's learning experience and challenges faced by them during the period of study. A study by Kaur and Sidhu (2008) shows that there are several dimensions in discussing students 'learning experiences at the postgraduate level. According to them, with an in-depth knowledge of the actual learning experience of postgraduate students it will be able to have a huge impact on the curriculum, discipline, culture and work practices at the university that can be changed through innovation.

According to Jeyaraj (2020) based on his study, it was found that the postgraduate students look forward to having the three main supports namely writing, supervision and ICT access. From the aspect of writing, students often get help by attending a relevant workshop as well as programs that offer them to enhance their knowledge on how to master thesis writing. They also believe that the supervisor's guidance is very important to help them from the 
aspect of writing and enlighten them related to the process and procedures requirements of the university. In fact, students also need easy access to ICT to assist them in producing writing.

Due to the student's challenges, a study by Kaur and Sidhu (2008) found that the main problems often experienced by postgraduate students are pressure to perform and meet the needs of postgraduate work, difficulty in adapting to new environment and academic culture, problems reading and understanding academic texts critically, writing using appropriate language, lack of knowledge in conducting research as well as the different cultural issues. Im Bok (2021); Baharudin, Murad \& Mat (2013), also explains other challenges faced by postgraduate students including family commitment, adjustment to learning and education funding. These challenges were found to affect adult learners who had many roles, and those challenges then became barriers to learning.

Past Studies for Writing among Postgraduates

There are many contributing factors that hinder the entire postgraduate writing process aside from language-related challenges. Abiddin (2011) stated that inaccessibility of guidance support and resources by the institution undesirably impacted student's quality of work and performance.

Based on the findings by Komba (2016), it seemed that the majority of the students were confused between the conclusion of the study and summary of the study in their dissertation. Besides, the students had not presented the recommendations appropriately as they lacked theoretical contribution to the topics under investigation. It is important to review research methods courses offered in the universities, in terms of teaching and content approaches. The weaknesses made by students can be minimized if this is properly done. Moreover, the universities also must attempt to subject all postgraduate students to any academic writing training, with focus mainly on how to write research reports.

Steps to alleviate untimely completion rates among postgraduate students can be addressed and areas which could lead to larger student satisfaction can be determined if identifying students' writing needs and areas of support have been done (Jeyaraj, 2020). It has been recognised that research supervision is vital to successful postgraduate completion. Highly successful supervisors adopt different practices depending on their students' needs and stage of candidatures since they recognised that supervision is not a one-size-fits-all model (Nulty et al., 2009).

Fergie et al (2011) posit that the postgraduate journey has frequently been labelled as isolating and lonely. Many institutions have addressed this problem by providing a variety of peer-related support services since this form of support has led to timely completion among students (Buissink-smith et al., 2013). To support the social aspect of writing, students can gather to give and receive feedback on their writing in their peer writing groups that have been set up.

To respond to the needs of students in increasing their writing motivation, there are support services and interventionist strategies regularly provided for students, typically by centralised departments that address writing skills and academic development (Carter, 2011). Skills 
based approaches have been implemented in the form of one-off thesis writing workshops programmes and add-on writing skills courses most of the time. Some examples include English for Academic Purposes (EAP) support programmes (Larcombe, 2007)

Conceptual Framework (Optional)

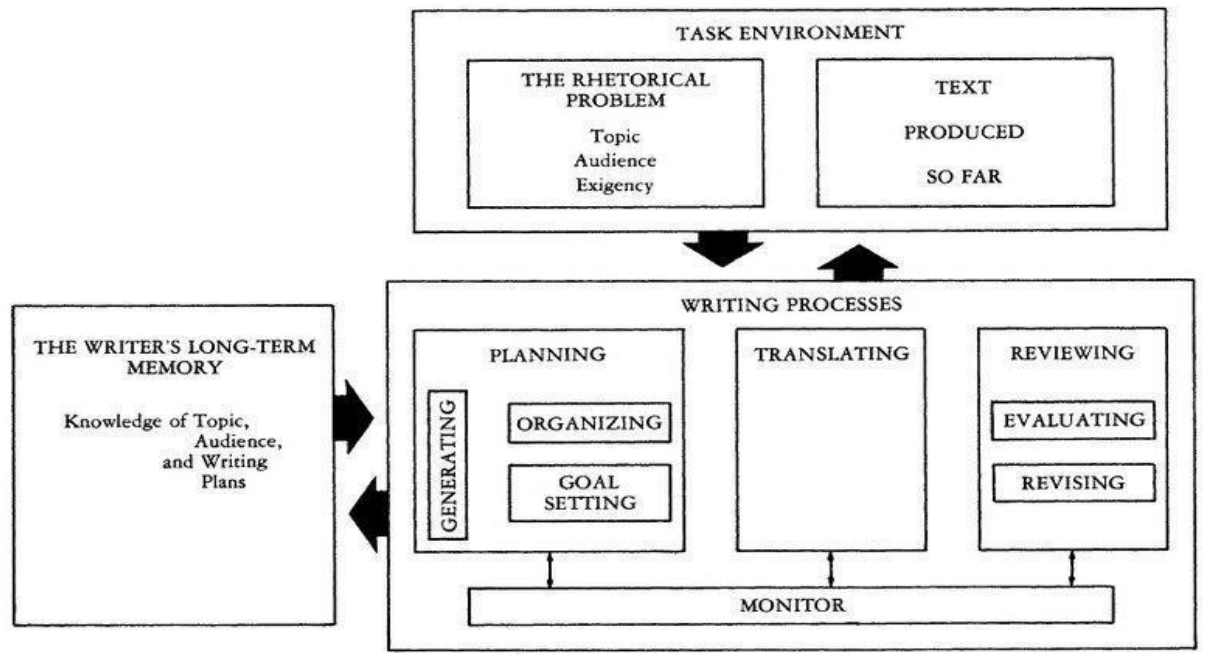

Figure 1-Rhetorical Problems (Source Flower \& Hayes, 1980)

Figure 1 above presents Flower \& Hayes's (1980) interpretation of the writing process. Flower and Hayes reported that writers go through three stages in the writing process. The first stage is the planning stage where the writers' generated ideas. Next, they would go through the translating stage. Translating here refers to translating writers' oral thoughts into written thoughts. The last stage is the reviewing stage where the writers evaluated and revised the writing done.

The three compartments in rhetorical problems by Flower \& Hayes (1980) reveal three important worrying factors for writers and they are (i) the writing process, (ii) the writers' own goals and (iii) the task environment. Nevertheless, the task environment for the writers in this study is the thesis writing. According to Rahmat (2019), teachers teaching academic writing would identify with the pains of imparting proper academic skills and conventions. Using Flower \& Hayes (1980) rhetorical problems (perception of audience, exigency, and topic) as the basis, the conceptual framework (figure 2) of this study explores the motivation learners (Pintrich, 1990) have for their thesis writing. Learners would put value to their writing assignment if they are aware of their audience. Next, the learner's expectancy is influenced by their perception of exigency and finally, their affective motivation is influenced by their perception of the topic. 


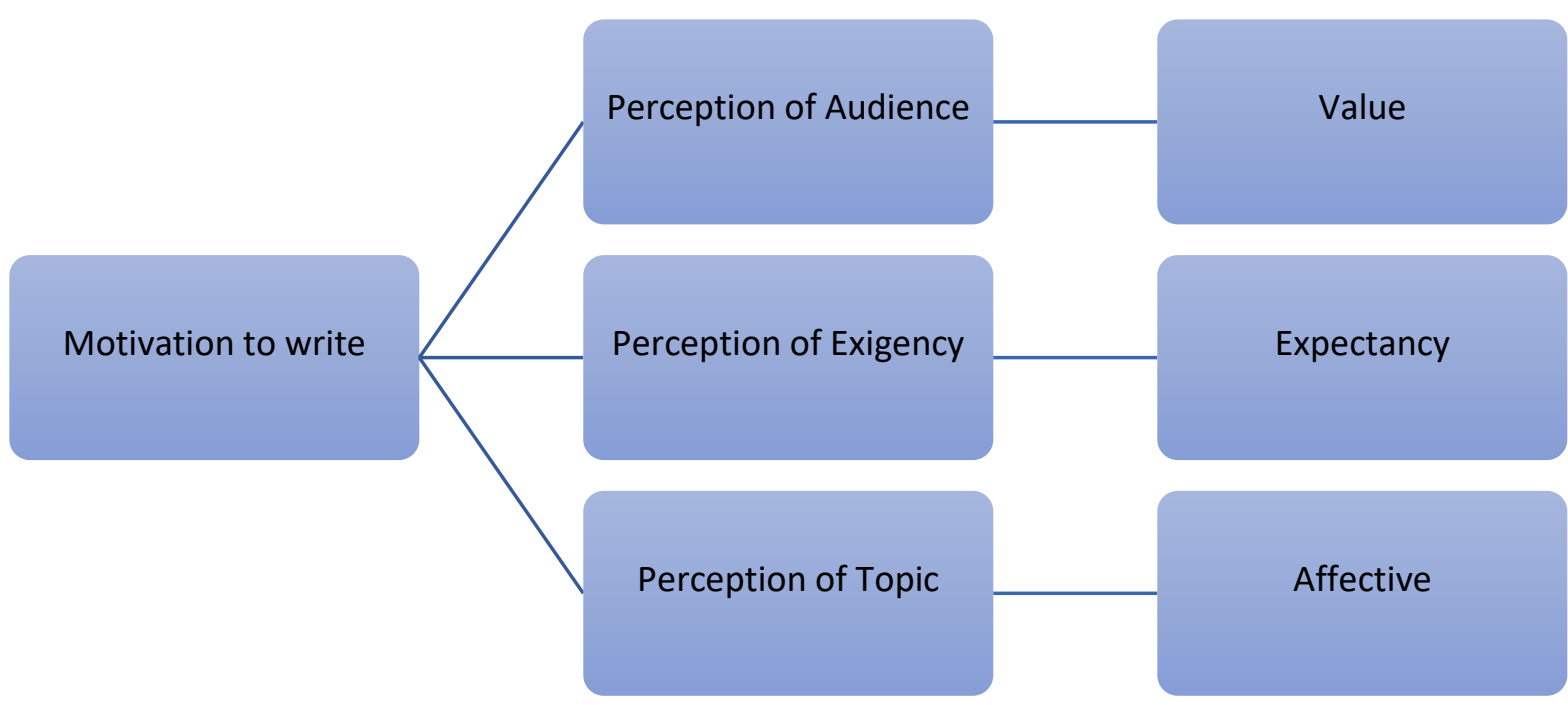

Figure 2- Conceptual Framework of the Study

(Source: Flowers \& Hayes, 1980; Pintrich, 1990)

\section{Methodology}

Research Design

This study utilizes cross-sectional quantitative research using questionnaires. Sampling was done conveniently in which the questionnaires were shared to the students in the program by the program head. The data collection was done once and the subjects are not influenced by any observation, thus making the result move valid and reliable. This study employs the mean statistic to explore rhetorical problems learners face in the writing of their thesis.

\section{Sample}

72 participants took part in this study. Of the population, $12(16.7 \%)$ were male and $60(83.3)$ females. Participants were randomly selected and were drawn from three FSPPP masters programs, comprising 33 (45.8 \%) EMAS, 21 (29.2) MIRAD and 18 (25\%) MOCA students. The numbers are proportional to the percentage of the actual population in the FSPPP.

\section{Instrument}

Pintrich (1990) Motivational and self- regulated learning Component of Classroom Academic performance, which represents a useful, reliable, and valid means for assessing students' motivation and self-regulated learning was adapted and used to establish the motivational component ( 24 items). The construct includes value component with three variables (intrinsic goals orientation ( 4 item), Extrinsic Goal Orientation ( 3 items), and Task Value belief ( 5 items), the Expectancy Component with two variables (Student's perception of Self-Efficacy (5 items) and Control beliefs for learning ( 2 item)) and finally the affective components as a variable itself with 5 items. E items uses a 5-point Likert scale anchored by "never" (1), "rarely" (2), "Sometimes" (3), "very often" (4) and "always" (5). Scale scores were obtained by computing the average of the item scores within a scale.

Nunnally (1978) recommended that the value of Cronbach's Alpha must be above 0.7 . Reliability test provides a measure of the extent of which the score reflects random measurement error, which may be caused by personal factors. The internal consistency 
reliability coefficient (Cronbach's Alpha) for the whole motivational scale and it subdimensions variable in table 1 was found to have a reliability coefficient of 0.890 which is greater than the acceptable level of reliability suggested Nunnally (1978)

Table 1: Reliability Result for Motivational Scale

\begin{tabular}{|l|l|l|}
\hline Dependent Variables & No of Items & Cronbach's Alpha \\
\hline Motivational Scale & 24 & 0.890 \\
\hline
\end{tabular}

Table 2: Motivational Scale

\begin{tabular}{|l|l|l|l|l|l|}
\hline SECT & CONSTRUCT & & VARIABLE & $\begin{array}{l}\text { No } \\
\text { Of } \\
\text { Items }\end{array}$ & $\begin{array}{l}\text { Total } \\
\text { Items }\end{array}$ \\
\hline A & VALUE COMPONENTS & (a) & Intrinsic Goal Orientation & 4 & 12 \\
\hline & & (b) & Extrinsic Goal Orientation & 3 & \\
\hline & (c) & Task Value Beliefs & 5 & \\
\hline B & $\begin{array}{l}\text { EXPECTANCY } \\
\text { COMPONENT }\end{array}$ & (a) & $\begin{array}{l}\text { Students' Perception of Self- } \\
\text { Efficacy }\end{array}$ & 5 & 7 \\
\hline & (b) & Control Beliefs for Learning & 2 & \\
\hline & & & & & \\
\hline C & AFFECTIVE COMPONENTS & & 24 \\
\hline & TOTAL NO OF ITEMS &
\end{tabular}

\section{Method of Data Collection}

The respondent data has been collected through a self-administered online questionnaire on motivational scale (table 2) distributed to the master's level students of FSPPP. The students were conveniently selected through an announcement made in the students' WhatsApp group. A link of the questionnaire using google form was given. A statement of concern and assurance that the data collected will be kept confidential for academic purposes.

Method of Data Analysis

Descriptive statistical techniques were used to analyse the data. When it came to the participants' motivating beliefs, measures of central tendency employing the mean analysis were used to explain each variable.

\section{Findings}

Findings for Demographic Profile

To summarize the demographic characteristics of the respondents, a frequency distribution analysis was. A total of 72 respondents obtained the research. the data is summarised in the Table 4.1 
Table 3: Demographic Profile

\begin{tabular}{|l|l|l|l|}
\hline & Respondent Background & Frequency & Percent (\%) \\
\hline Q1. & GENDER & & \\
\hline & Male & 12 & $17 \%$ \\
\hline & Female & 60 & $83 \%$ \\
\hline Q2 & PROGRAMME & & \\
\hline & EMAS & 33 & $46 \%$ \\
\hline & MOCA & 18 & $25 \%$ \\
\hline & MIRAD & 21 & $29 \%$ \\
\hline
\end{tabular}

Based on table 3, the frequency distribution of gender is $12(16.7 \%)$ were male and $60(83.3)$ females. The three FSPPP masters programs, comprising 33 (45.8\%) EMAS, 21 (29.2\%) MIRAD and $18(25 \%)$ MOCA students. All students are required to take the Research Method and Data Analysis course (EMA702 for EMAS and MIRAD and EMA705 for MOCA) as a prerequisite to writing a dissertation.

Findings for Audience Factor and Learners' Motivation

This section presents findings to answer research question 1: How does audience factor influence learners' motivation to write? Learners would put value to their writing assignment if they are aware of their audience. The value component analysed is divided into two categories (a) intrinsic goal orientation, (b) extrinsic goal orientation and (c) task value.

\section{(a) INTRINSIC GOAL ORIENTATION}

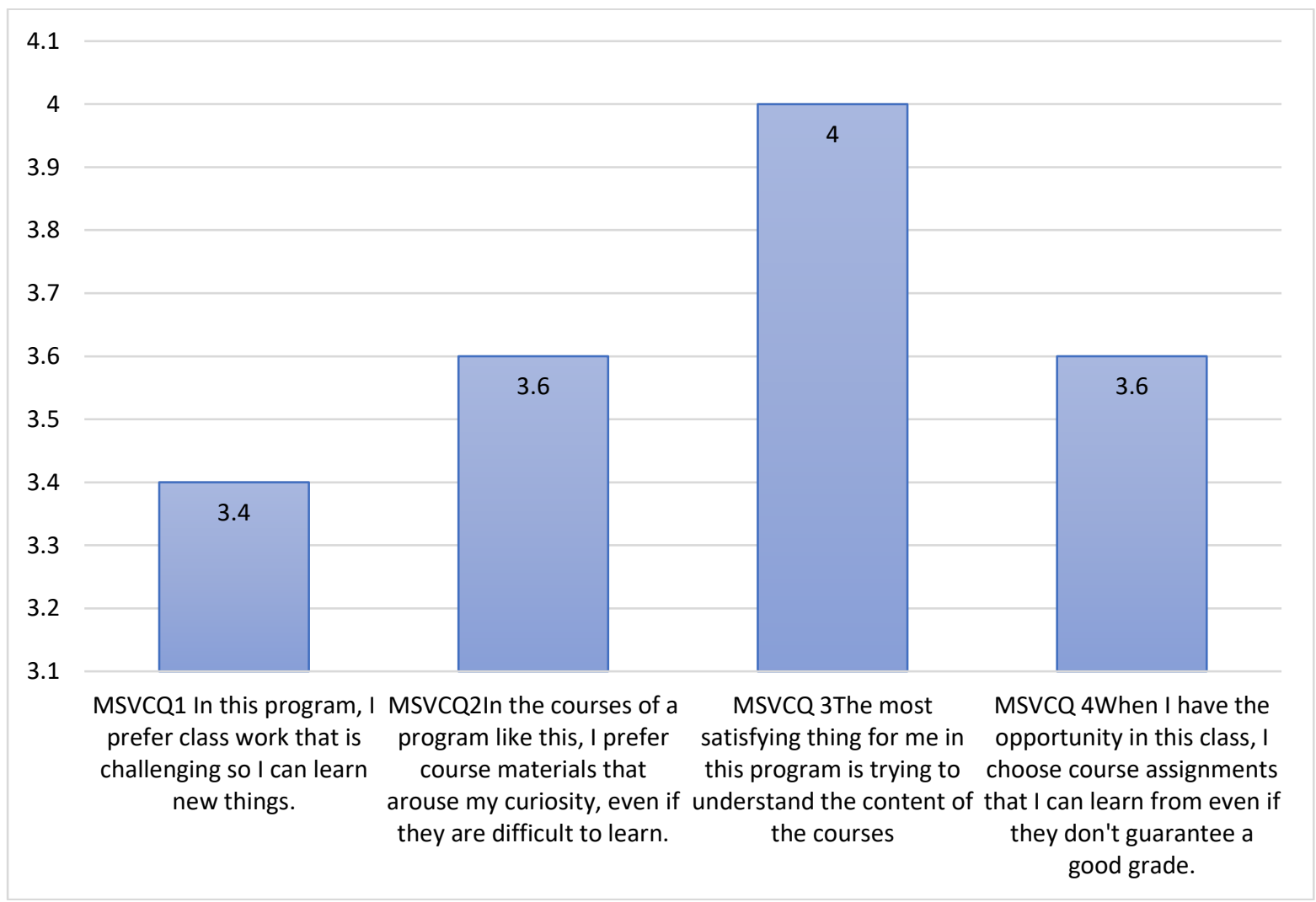

Figure 3-Mean for Intrinsic Goal Orientation 
Based on figure 3, the overall mean shows a moderately high value with the highest mean (4.0) under the statement "The most satisfying thing for me in this program is trying to understand the content of the courses". It means that it is important for them to feel satisfied in trying to understand the content of the courses. The second highest mean which is 3.6 can be seen from two statements which are "In the courses of a program like this, I prefer course materials that arouse my curiosity, even if they are difficult to learn" and "When I have the opportunity in this class, I choose course assignments that I can learn from even if they don't guarantee a good grade". Lastly the lowest mean is 3.4 in which they prefer class work that is challenging so they can learn new things.

\section{(b) EXTRINSIC GOAL ORIENTATION}

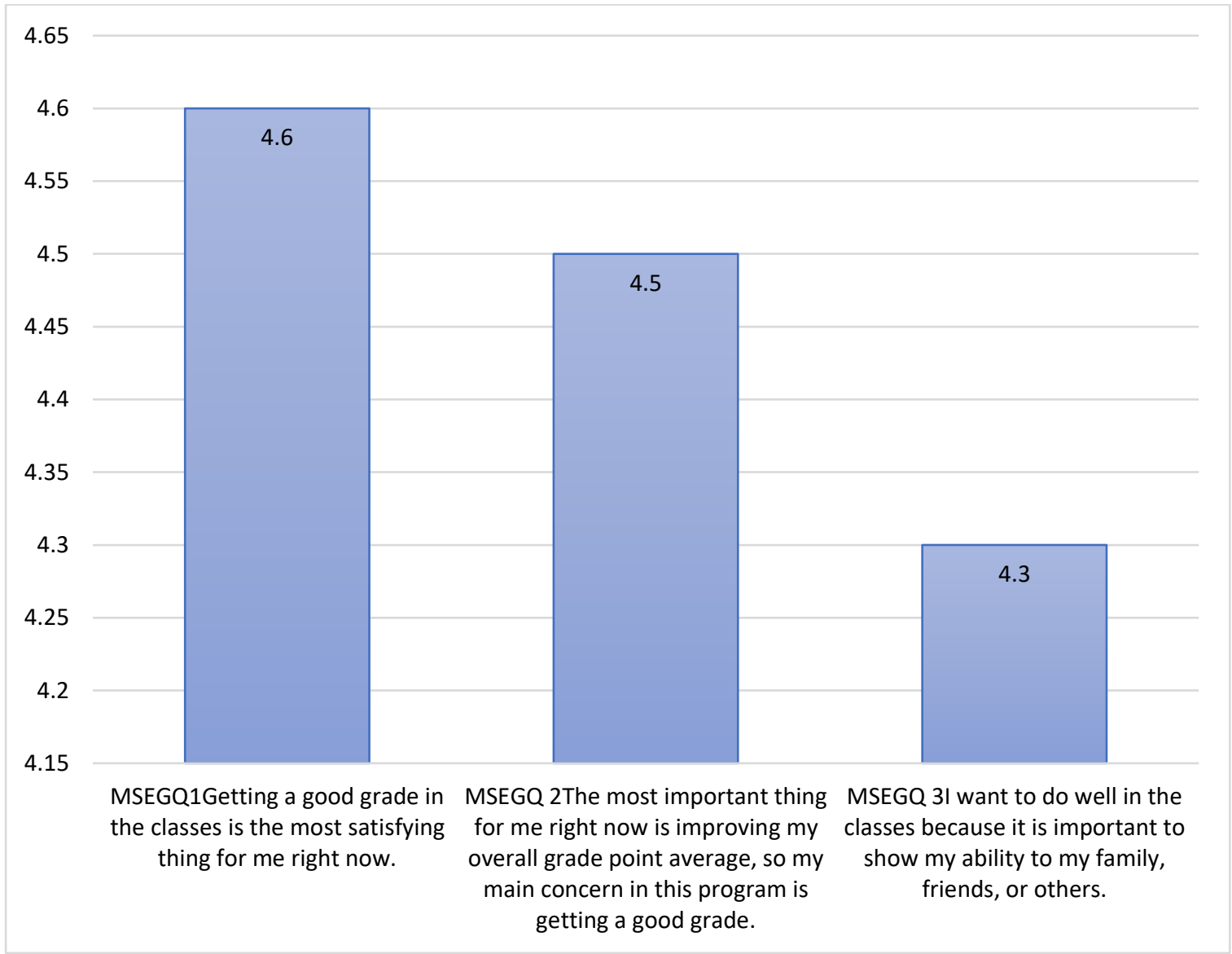

Figure 4-Mean for Extrinsic Goal Orientation

From figure 4 above, it can be inferred that the item with the highest mean $(M=4.6)$ lies on the statement of 'Getting a good grade in the classes is the most satisfying thing for me right now'. This means that most of the respondents strongly agreed that getting a good grade in the classes will increase their satisfaction. The next highest mean $(M=4.5)$ obtained was highlighted from the statement 'The most important thing for me right now is improving my overall grade point average, so my main concern in this program is getting a good grade', which means that majority of the respondents agreed to the fact that the most important matter for the students are to improve their overall grade point average. Finally, the item with the statement "I want to do well in the classes because it is important to show my ability to my family, friends, or others' shows the lowest mean $(M=4.3)$ in this category. This indicates 
that the respondents had found that they agreed that they want to show their ability to their family, friends or others.

\section{(c) TASK VALUE BELIEFS}

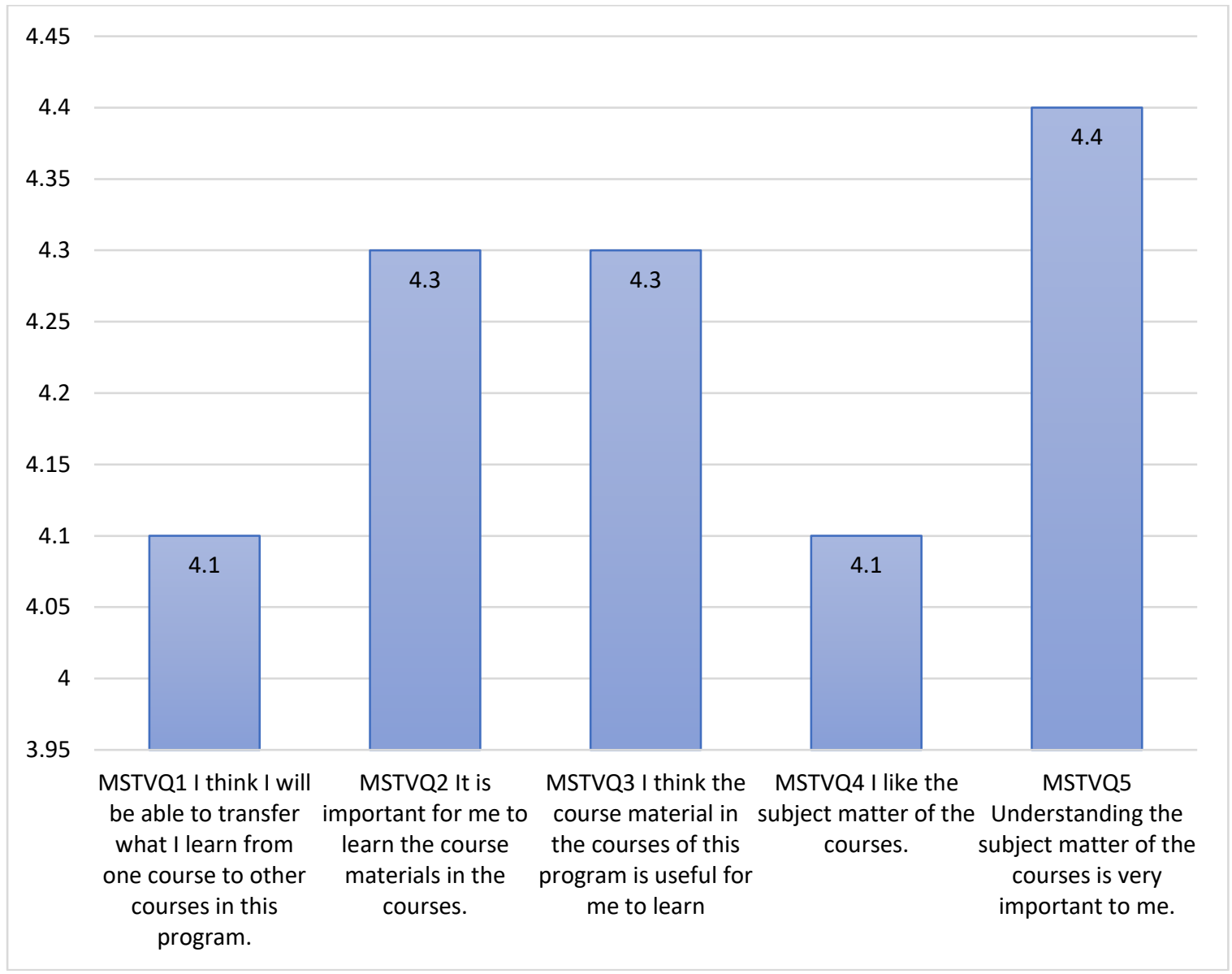

Figure 5 -mean for Task value Beliefs

Overall, the finding (figure 5) shows high mean scores for all items with scores above 4.0. The highest mean score for the task value beliefs is understanding the subject matter of the courses is important to me $(M=4.4)$. It can be inferred that the majority of the respondents believed that it is very important for them to understand the taught course. Whilst, the lowest mean scores are items on I think I will be able to transfer what I learn from one course to other courses in this program and I like the subject matter of the courses $(M=4.1)$. This indicates that the respondents felt that the course on research academic exercise is a final year dissertation that teaches them to apply the thrust discipline in their research work and most of them felt they liked the course very much.

Findings for RQ2

This section presents findings to answer research question 2: How does the exigency factor influence learners' motivation to write? The learner's expectancy is influenced by their perception of exigency. Expectancy component is further categorised as (a) students; perception of self-efficacy, and (b) control beliefs for learning. 


\section{(a) STUDENTS 'PERCEPTION OF SELF-EFFICACY}

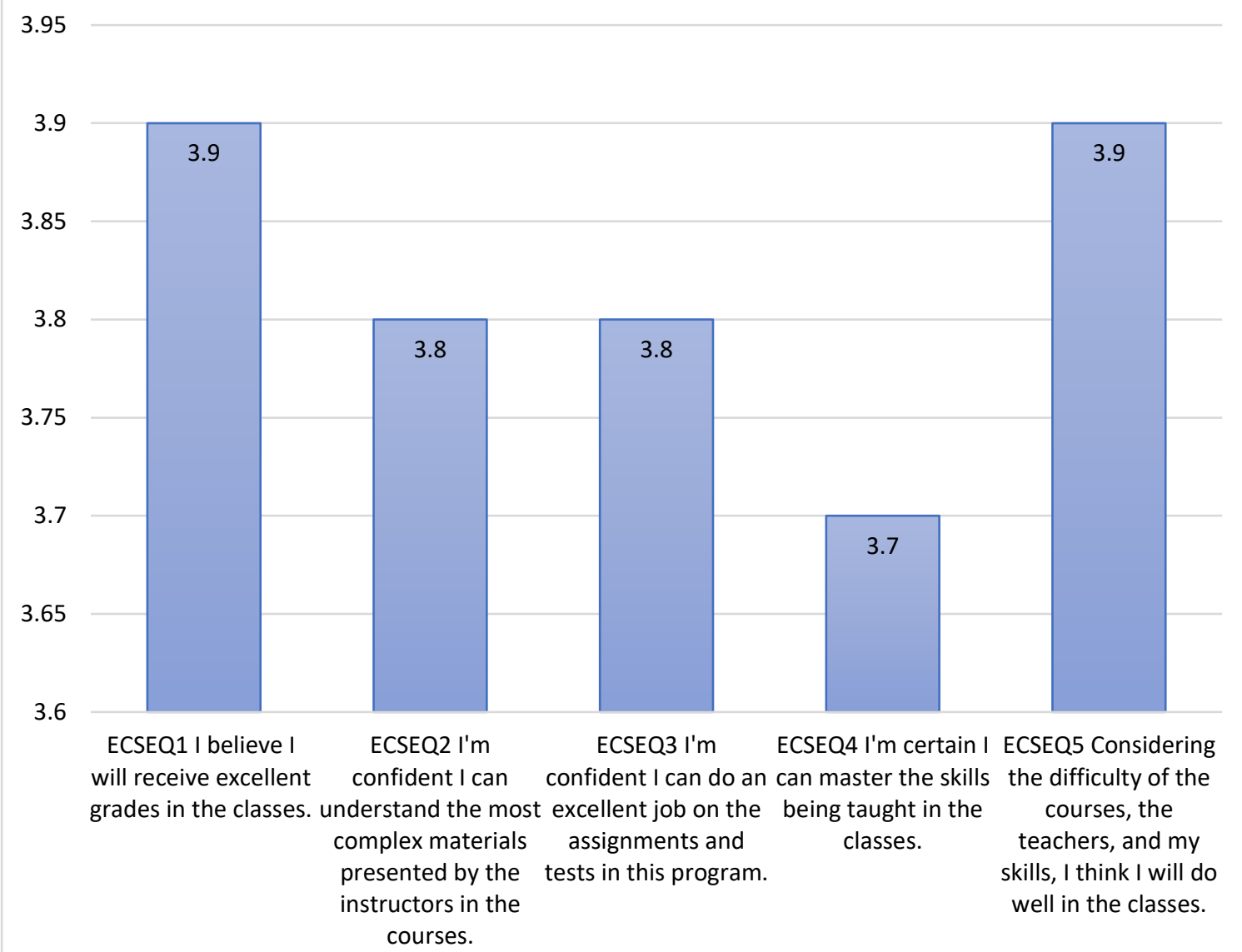

Figure 6- Mean for Students' Perception of Self-Efficacy

Figure 6 shows the respondents' perception of self-efficacy by looking into several dimensions. Overall, the mean indicates a moderately high value which is above 3.34 as suggested by Pallant (2007). The belief that they can receive excellent grades in classes and their capability to handle difficulties of the courses, teachers and skills recorded the highest value within this cluster which is 3.9, followed by their confident level to understand the most complex materials presented by the instructors in the courses as well as ability to excel in assignment and test in this program with value of 3.8. However, the belief that they can master the skills they have learned in class shows the lowest among others with mean 3.7. Thus, it can be concluded that the students have high belief and self-efficacy on their ability to excel in their studies. 


\section{(b) CONTROL BELIEFS FOR LEARNING}

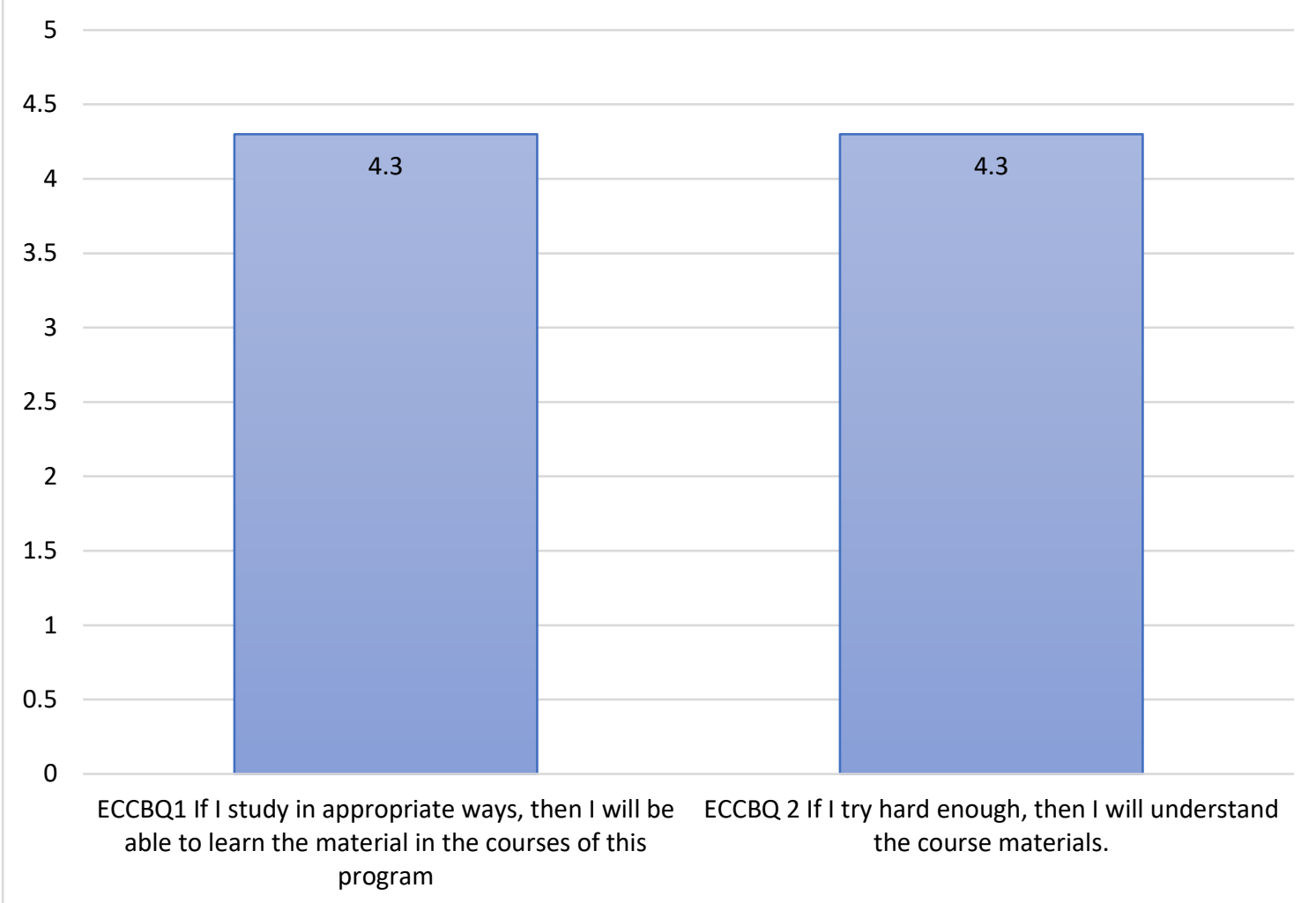

Figure 7-Mean for Control Beliefs for Learning

Figure 7 discusses the control beliefs for learning, in which both items have shared equal mean value which is 4.3 and it can be considered as high. It indicates that the students believe that if they study appropriately and put high commitment and effort, they will be able to understand the course material of the program.

Findings for RQ3

This section presents analysed data to answer research question 3: How does the topic influence learners' motivation to write? The learners' affective motivation is influenced by their perception of the topic. 


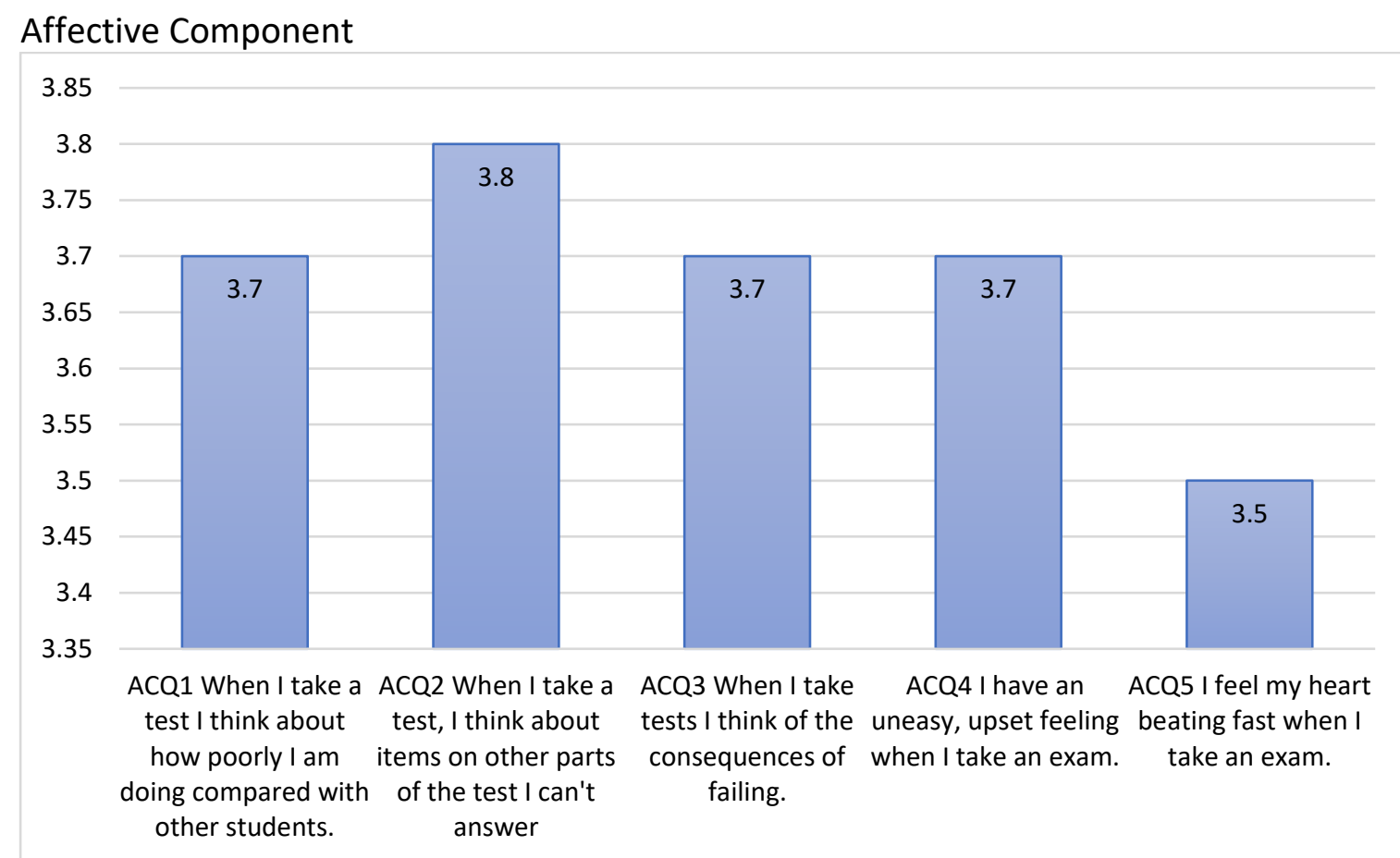

Figure 8-Mean for Affective Component

Figure 8 shows the Affective component overall mean score is moderately high in the range of 3.5 to 3.8. The highest in the Affective component scale is "when I take a test, I think about items on other parts of the test I cannot answer" ( $M=3.8)$ and the lowest is "I feel my heart beating fast when I take an exam" with a mean score of 3.5. The rest of the components score an equal mean of 3.7. This indicates that students motivationally are moderately affected by the need to complete a task that will test their knowledge and skills in this case exam.

\section{Conclusion}

\section{Summary of Findings and Discussion}

Based on the findings, it is found that the value component that includes intrinsic and extrinsic goal orientation portrayed the respondents' priority to make sure that they can better understand the real requirements in writing the dissertation. According to the respondents, mastering writing as well as giving commitment with high effort will be able to help them in completing their writing within the allotted time. In fact, getting a good grade for the dissertation could boost the student's satisfaction in writing.

These findings can be further supported by the study done by Ryan and Deci (2000) who found that most of the intrinsic and extrinsic stimuli factors could contribute to student motivation in writing. Hence, the attitude of students to understand the requirements in a piece of writing will give a lot of encouragement to them to complete the dissertation that has been entrusted.

\section{Pedagogical Implications}

The results of the study which has been developed under each item of the value component, expectancy component and affective component indicates that it is useful and vital to conduct this motivational scale for the teachers to take into consideration what factors that motivates and influences the postgraduate students to keep writing their dissertation. The teachers need to do improvement in their teaching skills, course syllabus and consider the student's 
ways of learning in order to increase student's motivation. This study gives insight on which are the factors that contribute the highest toward postgraduate student's motivation and what can the teachers do to help students based on the findings. For example, teachers can try creating a supportive social environment which is rich in social interaction in the classroom or through online learning.

\section{Suggestion for Future Research}

It is suggested for the researcher to do a wide-scale of research which involves students in different colleges/universities and states. This is because this research only covered a small scale of postgraduate students under UiTM. Future research might consider other factors related such as previous academic performance, previous experience with a teacher, class attendance and others.

\section{References}

Abiddin, N. Z. (2011). Attrition and Completion Issues in Postgraduate Studies for Student Development. International Review of Social Sciences and Humanities, 1(February), 1599.

https://www.researchgate.net/publication/312973059_Attrition_and_Completion_Iss ues_in_Postgraduate_Studies_for_Student_Development

Aryanika, S. (2016). The Correlation Between the Students' Writing Motivation and the Writing Ability. English Education: Jurnal Tadris Bahasa Inggris, 9(1), 215-232. https://media.neliti.com/media/publications/60527-EN-the-correlation-between-thestudents-wri.pdf

Baharudin, S. N. A., Murad, M., \& Mat, N. H. (2013). Challenges of Adult Learners: A Case Study of Full Time Postgraduates Students. Procedia - Social and Behavioral Sciences, 90, 772-781. https://doi.org/10.1016/j.sbspro.2013.07.151

Bandura, A. (1986). Social foundations of thought and action: A social cognitive theory. Prentice-Hall, Inc.

Bandura, A. (1997). Self-efficacy: The exercise of control. New York: Freeman.

Birkenkrahe, M. (2014). Using storytelling methods to improve emotion, motivation and attitude of students writing scientific papers and theses. Proceedings of 2014 IEEE 13th International Conference on Cognitive Informatics and Cognitive Computing, ICCl ${ }^{*} \mathrm{CC}$, 140-145. https://doi.org/10.1109/ICCI-CC.2014.6921453

Buissink-smith, N., Hart, S., \& Meer, J. Van Der. (2013). 'There are other people out there!' Successful postgraduate peer groups and research communities at a New Zealand university. Higher Education Research \& Development, 32(5), 695-705. https://doi.org/10.1080/07294360.2013.777034

Chin, W. Y., Ch'ng, C. K., Jamil, J. M., \& Shaharanee, I. N. M. (2017). Analyzing the factors that influencing the success of post graduates in achieving graduate on time (GOT) using analytic hierarchy process (AHP). In AIP Conference Proceedings, 1905, 1, 040009. AIP Publishing LLC. https://doi.org/10.1063/1.5012197

Dörnye, Z., \& Ushiod, E. (2011). Teaching and Researching Motivation. $2^{\text {nd }}$ Edition, Pearson Education Limited: United Kingdom

Dörnyei, Z., \& Ushioda, E. (2013). Teaching and researching motivation. 2ndEdition, Pearson Education Limited: United Kingdom. https://doi.org/10.4324/9781315833750

Durso, S. D. O., Cunha, J. V. A. D., Neves, P. A., \& Teixeira, J. D. V. (2016). Motivational factors for the master's degree: A comparison between students in accounting and economics 
in the light of the self-determination theory. Revista Contabilidade \& Finanças, 27, 243258. https://doi.org/10.1590/1808-057x201602080

Fergie, G., Beeke, S., Mckenna, C., \& Creme, P. (2011). "It' s a Lonely Walk": Supporting Postgraduate Researchers through Writing, 23(2), 236-245. http://www.isetl.org/ijtlhe/pdf/ijtlhe1016.pdf

Floris, M. V. B., Nadira S., Roeland M. V.D. R., Marleen S. D., Aaltje S. B.V.D.B. \& Paul W.V.D.B. (2019). How do self-efficacy beliefs for academic writing and collaboration and intrinsic motivation for academic writing and research develop during undergraduate research project? Educational

Studies, 45(2), 209-225. https://doi: 10.1080/03055698.2018.1446326

Flower, L., \& Hayes, J. R. (1980). The cognition of discovery: Defining a rhetorical problem. College Composition and Communication, 31(1): 21-32. https://doi.org/10.2307/356630

Greene, C., Zugelder, B. S., Warren, L. L., \& L'Esperance, M. (2020). What Factors Influence Motivation for Graduate Education? Critical Questions in Education, 11(1), 21-37. https://eric.ed.gov/?id=EJ1287209

Hadi, N. U., \& Muhammad, B. (2019). Factors Influencing Postgraduate Students' Performance: A high order top-down structural equation modelling approach. Educational Sciences: Theory \& Practice, 19(2). https://doi.org/10.12738/estp.2019.2.004

Harbour, K. E., Evanovich, L. L., Sweigart, C. A., \& Hughes, L. E. (2014). A Brief Review of Effective Teaching Practices That Maximize Student Engagement. Preventing School Failure: Alternative Education for Children and Youth, 59(1), 5-13. https://doi.org/10.1080/1045988X.2014.919136

Heide, S., Pante, S. V., Fleig, A., Möltner, A., Leis, S., Fritz, A. H., ... \& Fischer, M. R. (2019). Individual and institutional influencing factors on completion rates in a medical education master's program in Germany. GMS journal for medical education, 36(6). https://www.ncbi.nlm.nih.gov/pmc/articles/PMC6905360/

Im Bok, G. (2021). Adult learners' challenges in distance learning: A case study in Universiti Sains Malaysia. Issues in Educational Research, 31(1).

https://www.iier.org.au/iier31/bok.pdf

Jeyaraj, J. J. (2020). Academic writing needs of postgraduate research students in malaysia, 17(2), 1-23. https://files.eric.ed.gov/fulltext/EJ1272188.pdf

Jeyaraj, J. J. (2020). Academic writing needs of postgraduate research students in Malaysia. Malaysian Journal of Learning and Instruction,17(2), 1-23.

https://doi.org/10.32890/mjli2020.17.2

Kaur, S., \& Sidhu, G. K. (2009). A Qualitative Study of Postgraduate Students' Learning Experiences in Malaysia. International Education Studies. 2(3):47-56. DOI: 10.5539/ies. v2n3p47

Komba, S. C. (2016). Challenges of writing theses and dissertations among postgraduate students in Tanzanian higher learning institutions, International Journal of Research Studies in Education, 5(3), 71-80.DOI: 10.5861/ijrse.2015.1280

Larcombe, W. (2007). Supporting Education PhD and DEd Students to Become Confident Academic Writers: an Evaluation of Thesis Writers' Circles Supporting Education PhD and DEd Students to Become Confident Academic, 4(1).

https://ro.uow.edu.au/jutlp/vol4/iss1/6/ 
Litalien, D., Guay, F., \& Morin, A. J. (2015). Motivation for PhD studies: Scale development and validation. Learning and individual differences, 41, 1-13. https://doi.org/10.1016/j.lindif.2015.05.006

Moore, S. (2003). Writers' retreats for academics: exploring and increasing the motivation to write. Journal of Further and Higher Education, 27(3), 333-342. https:// doi:10.1080/0309877032000098734.

Munyengabe, S., Haiyan, H., Liangyan, S. \& Yiyi, Z. (2017). Motivation to pursue PhD studies in mathematics and sciences studies among international students in a Research University. Eurasia Journal of Mathematics, Science and Technology Education, 13(12), 8027-8037. https://doi.org/10.12973/ejmste/80754

Nayir, F. (2017). Eurasian Journal of Educational Research The Relationship between Student Motivation and Class Engagement Levels. Funda NAYIR Eurasian Journal of Educational Research, 71, 59-78. https://doi.org/10.14689/ejer.2017.71.4

Ng, S. F., Muhd, N. M. N., Ab Rahman, K., \& Ismail, N. (2011). Influential factors to pursue doctorate degree in Malaysia. Procedia-Social and Behavioral Sciences, 15, 2028-2032. https://doi.org/10.1016/j.sbspro.2011.04.048

Nulty, D., Kiley, M., \& Meyers, N. (2009). Assessment \& Evaluation in Higher Education Promoting and recognising excellence in the supervision of research students: an evidence - based framework, 37-41. https://doi.org/10.1080/02602930802474193

O'Kennedy, R. (1990). Motivation of postgraduate students. Biochemical Society Transactions. DOI: $10.1042 /$ bst0180161.

Pajares, F. (2003). Self-efficacy beliefs, motivation, and achievement in writing: a review of the literature, Reading \& Writing Quarterly: Overcoming Learning Difficulties, 19(2), 139-158. https://doi.org/10.1080/10573560308222

Pintrich, P. R., \& De Groot E. V. (1990). Motivational and self-regulated learning Components of classroom academic performance. Journal of Educational Psychology, 82(1), 33-40. http://dx.doi.org/10.1037/0022-0663.82.1.33

Prat-Sala, M., \& Redford, P. (2012). Writing essays: Does self-efficacy matter? The relationship between self-efficacy in reading and in writing and undergraduate students' performance in essay writing. Educational Psychology. 32(1), 9-20. https://doi.org/10.1080/01443410.2011.621411.

Rahmat, N.H. (2019). Problems with Rhetorical Problems among Academic Writers. American Journal of Social Sciences and Humanities, 4(4), 506-515. http:// doi.org. / 10.20448/801.44.506.515

Ryan, R. M., \& Deci, E. L. (2000). Intrinsic and Extrinsic Motivations: Classic Definitions and New Directions. Contemporary Educational Psychology, 25(1), 54-67. https://doi.org/10.1006/CEPS.1999.1020

Sanders-Reio, J., Alexander, P.A., Reio, T.G., Newman, I. (2014). Do students' beliefs about writing relate to their writing self-efficacy, apprehension, and performance? Learning and Instruction, 33,1-11. https://doi:10.1016/j.learninstruc.2014.02.001

Schunk, D. H., \& Zimmerman, B. (Eds.) (1994). Self-regulation of learning and performance: Issues and educational applications. Hillsdale, NJ: Lawrence Erlbaum Associates.

Schunk, D. H. (1991). Self-Efficacy and Academic Motivation. Educational Psychologist, 26 (34),207-231. https://doi:10.1207/s15326985ep2603\&4_2.

Teowkul, K., Seributra, N. J., Sangkaworn, C., Jivasantikarn, C., Denvilai, S., \& Mujtaba, B. G. (2009). Motivational factors of graduate Thai students pursuing master and doctoral degrees in business. $R U$ international Journal, 3(1), 25-56. 
https://citeseerx.ist.psu.edu/viewdoc/download?doi=10.1.1.464.3924\&rep=rep1\&typ $\mathrm{e}=\mathrm{pdf}$

Tokan, M. K., \& Imakulata, M. M. (2019). The effect of motivation and learning behaviour on student achievement. South African Journal of Education, 39(1), 1-8. https://doi.org/10.15700/saje.v39n1a1510

Uka, A. (2012). Motivational factors of albanian graduate students pursuing a master degree in education. Beder Journal of Educational Sciences, 1. http://dspace.epoka.edu.al/handle/1/2000

Van Rooij, E., Fokkens-Bruinsma, M., \& Jansen, E. (2021). Factors that influence PhD candidates' success: the importance of PhD project characteristics. Studies in Continuing Education, 43(1), 48-67. https://doi.org/10.1080/0158037X.2019.1652158

Zimmerman, B. J., \& Martinez-Pons, M. (1990). Student differences in self-regulated learning: Relating grade, sex, and giftedness to self-efficacy and strategy use. Journal of Educational Psychology, 82, 51-59. https://doi.org/10.1037/0022-0663.82.1.51

Zimmerman, B. J., \& Risemberg, R. (1997). Becoming a self-regulated writer: A social cognitive perspective. Contemporary Educational Psychology, 22, 73-101. https://doi.org/10.1006/ceps.1997.0919

Zimmerman, B., \& Bandura, A. (1994). Impact of self-regulatory influences on writing course attainment. American Education Research Journal. 31, 845-862.

https://doi.org/10.3102/00028312031004845 